\title{
Kajian Hukum Pidana Indonesia atas Penyalahgunaan Alat Bukti Visum Et Repertum sebagai Sarana untuk Melakukan Tindak Pidana Pemerasan
}

\author{
Rohmat \\ Universitas Negeri Semarang \\ Semarang, Indonesia \\ Jl. Kampus Timur, Sekaran, Gunungpati, \\ Kota Semarang, Jawa Tengah 50229
}

Surel: rohmatfhukum@gmail.com

\author{
Prasasti Dyah Nugraheni \\ Universitas Negeri Semarang \\ Semarang, Indonesia \\ Jl. Kampus Timur, Sekaran, Gunungpati, \\ Kota Semarang, Jawa Tengah 5022
}

Surel: prasastidyahnugraheni@gmail.com

\begin{abstract}
ABSTRAK
Visum et Repertum oleh beberapa orang dapat disalahgunakan oleh beberapa orang untuk menguntungkan diri sendiri secara ilegal. Masalah dalam makalah ini adalah bagaimana posisi bukti Visum et Repertum dalam studi Pidana Indonesia KUHAP, kekuatan bukti Visum et Repertum dan bagaimana studi hukum pidana Indonesia terhadap bukti Visum et Repertum adalah digunakan sebagai alat untuk melakukan kejahatan pemerasan. Jenis penelitian ini menggunakan penelitian analisis normatif. Bahan penelitian yang digunakan adalah sekunder. Maka metode pengumpulan data dilakukan melalui studi literatur, sedangkan analisis data dilakukan secara kualitatif. Berdasarkan hasil dapat dikatakan bahwa kekuatan bukti Visum et Repertum hanya sebagai instrumen pelengkap dalam mencari kebenaran. Seseorang yang dengan sengaja menggunakan post mortem untuk keuntungan secara ilegal, maka orang tersebut tidak dapat dianggap sebagai korban tapi pelaku lain yang berhubungan dengan saksi. Berdasarkan analisis unsur pidana dalam aliran monistik dan unsur pertanggungjawaban pidana dalam aliran dualistik, para pelaku kejahatan ini telah memenuhi unsur Dolus. Penelitian dapat disimpulkan bahwa hukum pidana Indonesia belum secara langsung dikendalikan itu. Dapat dikatakan bahwa kekuatan bukti Visum et Repertum hanya sebagai instrumen pelengkap dalam mencari kebenaran. Seseorang yang dengan sengaja menggunakan post mortem untuk keuntungan secara ilegal, maka orang tersebut tidak dapat dianggap sebagai korban tapi pelaku lain yang berhubungan dengan saksi. Berdasarkan analisis unsur pidana dalam aliran monistik dan unsur pertanggungjawaban pidana dalam aliran dualistik, para pelaku keiahatan ini telah memenuhi unsur Dolus.
\end{abstract}

\section{RIWAYAT ARTIKEL}

Article History

Diterima : 10 September 2019

Dipublikasi : 25 November 2019

\section{KATA KUNCI}

Keywords

Visum et Repertum, Pemerasan,

Bukti, Pertanggungjawaban Pidana

\section{HOW TO CITE (saran perujukan):}

Rohmat, Nugraheni, P.D. (2019). "Kajian Hukum Pidana Indonesia atas Penyalahgunaan Alat Bukti Visum Et Repertum sebagai Sarana untuk Melakukan Tindak Pidana Pemerasan", Lex Scientia Law Review. Volume 3 No. 2, November, hlm.191204. 


\section{PENDAHULUAN}

Berdasarkan Pasal 1 ayat (3) UUD 1945 Republik Indonesia menyatakan bahwa Indonesia adalah negara hukum. Ini berarti konsekuensi bahwa setiap lini kehidupan di negeri ini diatur dan memiliki dasar hukum. hukum adalah seluruh peraturan yang mengatur memaksa perilaku manusia dan memiliki sanksi jika melanggar dan dibuat oleh badan yang berwenang. Indonesia sebagai negara hukum yang menempatkan Pancasila dan UUD 1945 Republik Indonesia sebagai dasar filsafat dan dasar negara memiliki konsekuensi bahwa setiap tindakan dan peraturan yang dibuat harus berdasarkan Pancasila sebagai landasan tolol dan 1945 Undang dasar Negara Republik Indonesia sebagai landasan konstitusional.

Hal ini ditegaskan dalam Pasal 28G UUD 1945 Republik Indonesia yang menyatakan bahwa setiap orang memiliki hak untuk pribadi, keluarga, kehormatan, martabat, dan harta di bawah kekuasaannya, serta berhak untuk rasa aman dan perlindungan diri dari ancaman ketakutan untuk berbuat atau tidak berbuat sesuatu yang merupakan hak asasi manusia. Namun, dalam prakteknya kadang-kadang rasa aman dan perlindungan yang diterima oleh setiap warga negara belum diperoleh sepenuhnya.

Dalam tulisan ini, penulis mencoba untuk meneliti kemungkinan masalah yang dapat terjadi di masa depan dan belum memiliki dasar hukum yang jelas. Misalnya, kondisi ketika seseorang yang memiliki niat dan sengaja mencoba untuk memukul atau memprovokasi seseorang dari kemarahan dengan maksud orang yang terprovokasi akan membalas dengan melakukan pukulan ditujukan padanya. Dalam kasus seperti itu, hal yang bisa terjadi adalah bahwa orang yang dengan sengaja ingin pukulan atau luka akan melakukan post mortem dan kemudian hasil pos mortem akan digunakan untuk memeras dan meminta jumlah uang terhadap orang yang adalah timbal balik tidak melaporkan hal itu ke pihak berwenang menggunakan bukti visum dia sengaja.

Bukti visum kemudian sengaja digunakan sebagai alat untuk melakukan kejahatan pemerasan. Proses pelaporan dilakukan oleh seseorang tentu harus dilengkapi dengan bukti pendukung. Visum itu sendiri adalah bukti ilmiah yang dibuat oleh dokter karena keahlian mereka. Masalah timbul dan menjadi masalah adalah ketika hasil pos mortem tidak hasil yang tidak luka atau memar yang diperoleh sengaja dan digunakan untuk tindakan yang bertentangan dengan hukum. Visum adalah pengungkapan kasus menunjukkan peran penting bagi polisi. Ini adalah melalui bukti ini bahwa unsur kejahatan yang dilakukan oleh seseorang akan ditemukan.

Jika masalah tersebut terjadi, hukum pidana Indonesia harus mampu menjawabnya. Dalam KUHP, ada asas legalitas yang menyatakan bahwa 
"Tidak ada tindakan dapat dihukum, kecuali ketentuan aturan pidana dalam undang-undang yang ada sebelum perbuatan itu dilakukan". Pemerasan adalah tindakan yang dapat terjadi di mana saja dan kapan saja dan kadang-kadang pelaku pemerasan melihat kesempatan dan momentum untuk mencapai tujuan yang diinginkan. Menurut E. Utrecht, Pasal 1 ayat (1) KUHP mengandung pengertian bahwa hanya tindakan yang tegas disebut oleh peraturan perundang-undangan sebagai kejahatan dan pelanggaran dapat dikenakan sanksi pidana. Namun, jika ada peraturan mengatur itu, maka ini bukan suatu tindakan yang dapat dikenakan sanksi hukum (Djindang, 1983:338).

Masalah kaleng semacam ini, pada dasarnya, terjadi di masyarakat pada umumnya namun tidak ditindaklanjuti oleh korban. Penelitian ini akan meninjau kekuatan yang dimiliki oleh Visum et Repertum jika insiden disengaja terjadi untuk mendapatkan penyiksaan dan mendapatkan hasil visum berdasarkan studi hukum pidana Indonesia. Juga, makalah ini akan memeriksa pandangan hukum pidana Indonesia terhadap bukti Visum et Repertum sebagai alat untuk melakukan kejahatan pemerasan.

\section{Metode Penulisan}

Penelitian ini menggunakan penelitian kualitatif dengan pendekatan yuridis normatif. Pendekatan yuridis normatif dilakukan dengan memeriksa bahan pustaka atau data sekunder sebagai dasar untuk penelitian dengan mencari peraturan dan literatur yang berhubungan dengan masalah yang diteliti. Sumber-sumber dalam penelitian ini terdiri dari bahan hukum sekunder, yaitu bahan yang dikumpulkan dari peraturan perundang-undangan, kutipan, buku, jurnal, dan lain-lain yang terkait dengan penelitian ini.

Norma-norma yang terkandung dalam Pasal 368 KUHP, memiliki empat pelanggaran ini yaitu pertama dengan maksud untuk menguntungkan diri sendiri atau orang lain. Kedua, melawan hukum. Ketiga, memaksa seseorang dengan kekerasan atau ancaman. Keempat, untuk memberikan item, semua atau bagian dari itu milik orang itu atau orang lain, atau untuk membuat utang atau write off utang. Dalam hal ini, penulis menekankan norma melawan hukum, dalam makalah ini akan diperiksa mengenai penggunaan bukti visum sebagai alat untuk melakukan tindakan pemerasan melawan hukum.

Data yang diperoleh dalam penelitian ini akan dianalisis secara deskriptif kualitatif dan berdasarkan pada rumusan masalah yang telah ditentukan, yang kemudian akan mendapatkan kebenaran yang kemudian akan terkandung dalam kalimat disusun secara sistematis dan rinci. 


\section{PEMBAHASAN}

\section{A. Perspektif Hukum Progresif Posisi Bukti Visum et Repertum di Indonesia} dalam KUHAP

Definisi bukti adalah segala sesuatu yang ada hubungannya dengan tindakan, dimana dengan bukti, dapat digunakan sebagai bukti untuk membuat kepercayaan hakim kebenaran tindak pidana yang dilakukan oleh terdakwa (Haryanti. Jurnal Constitutum, Vol. 13, No. 1, 2013: 602). Berdasarkan ketentuan hukum acara pidana Indonesia, khususnya KUHAP secara eksplisit tidak menjelaskan arti dari Visum et Repertum. Ketentuan-satunya hukum yang memberikan pemahaman catok ini Staatsblad Tahun 1937 Nomor 350. Hal ini menyatakan bahwa Visum et Repertum adalah laporan tertulis untuk kepentingan pengadilan atas permintaan dari pihak yang berwenang, yang dibuat oleh dokter, dari segala sesuatu yang dilihat dan ditemukan dalam pemeriksaan bukti, berdasarkan sumpah saat menerima posisi, dan berdasarkan pengetahuan terbaik (Trisnadi, Sains Medika, Vol. 5, No. 2, Juli-Desember 2013:126). Visum et Repertum berasal dari kata "visual" yang berarti untuk melihat dan "repertum" yang berarti laporan. Jadi dengan demikian dapat dikatakan bahwa Visum et Repertum berarti apa yang dilihat dan ditemukan. Visum adalah laporan tertulis dari dokter (ahli) yang dibuat berdasarkan sumpah, tentang apa yang dilihat dan ditemukan, maka pemeriksaan berdasarkan pengetahuan terbaik. Visum et Repertum digunakan sebagai ajang pembuktian untuk menggantikan tubuh manusia yang pengalaman kekerasan (corpus delicti), oleh karena itu bukti catok ini diperlukan (Santoso, Jurnal Ilmiah WIDYA, Vol. 3, No. 3, Januari-Juli 2016:129). Dengan demikian, Visum et Repertum adalah opini dari seorang ahli (dokter) dalam menulis sebagaimana tercantum dalam bagian dari hasil pemeriksaan. Oleh karena itu, Visum et Repertum dibuat hanya untuk memperjelas kasus ini dan digunakan untuk pemeriksaan dan keadilan dan ditujukan untuk kepentingan peradilan dan bukan untuk tujuan lain.

Dalam sistem peradilan pidana dengan proses hukum atau model pendekatan pengendalian kejahatan, Visum et Repertum merupakan instrumen penting untuk membuktikan kebenaran faktual terkait dengan kasus pidana tertentu, khususnya kasus pidana dengan kekerasan (Adyan, Keadilan Progresif, Vol. 1, No. 1, 2010: 36). Proses pembuktian di persidangan sangat diperlukan. Hal ini sebagaimana ditegaskan dalam Pasal 179 ayat (1) Undang-Undang Nomor 8 Tahun 1981 tentang KUHAP, yaitu "Setiap orang diminta pendapatnya sebagai ahli medis peradilan atau dokter 
atau ahli lain harus memberikan informasi ahli oleh hukum". Dan posisi informasi ahli dalam hal ini sangat penting.

Bukti dalam persidangan yang dilakukan oleh dokter baik secara lisan maupun tulisan. Adapun secara tertulis, dapat dilakukan melalui Visum et Repertum. Selain itu, dapat dilihat dari penjelasan Pasal 186 dari KUHAP yang menyatakan bahwa "kesaksian ahli juga telah diberikan pada saat pemeriksaan oleh penyidik dan penuntut umum yang kemudian dilaporkan dalam bentuk ditulis dan laporan yang dapat dibacakan pada sidang". Selanjutnya, sebagaimana tercantum dalam Pasal 162 dan Pasal 179 ayat (2) dari KUHAP, menyatakan bahwa ahli dibuat dalam bentuk tertulis atau bentuk laporan yang dapat dibaca di pengadilan jika ada kendala dan tidak bisa di hadir pengadilan. Jadi, berdasarkan ketentuan pasal tersebut, informasi yang dapat dinilai sebagai bukti.

Ketika proses peradilan yang sedang berlangsung, dan hakim masih diragukan sebagai bukti dari Visum et Repertum bukti, hakim bisa memanggil dokter yang membuat visum dan menjelaskan dan bertanggung jawab atas hasil. Jadi ini telah diatur dalam Pasal 180 ayat (1) dari KUHAP. Dalam hal mengambil tanggung jawab atas Visum et Repertum dalam persidangan, hakim menyebut dokter yang membuat visum dan ini juga bisa sekaligus sebagai bukti kesaksian ahli di bidang kedokteran forensik yang untuk memperjelas masalah yang timbul dalam proses pengadilan. Pada tahap pemeriksaan di pengadilan, jika hakim ketua menganggap perlu untuk mengambil sumpah atau janji setelah ahli selesai memberikan pernyataan, maka sumpah di pengadilan akan dilakukan (Siadari, dkk, Diponegoro Law Journal, Vol. 5, No. 3, 2016:10-11). Tujuan dari Visum et Repertum termasuk sebagai bukti surat seperti yang dijelaskan sebelumnya karena surat itu dibuat pada sumpah jabatan sehingga surat tersebut memiliki kekuatan dan otentik. Hal ini ditegaskan dalam Pasal 187 Undang-Undang Nomor 8 Tahun 1981 tentang KUHP, yang menegaskan bahwa surat sebagaimana dimaksud dalam Pasal 184 ayat (1) huruf c, dibuat atas sumpah jabatan atau dikuatkan dengan sumpah, pernyataan dari seorang ahli di dalamnya mengandung opini berdasarkan keahliannya mengenai suatu hal atau situasi yang secara resmi meminta dirinya (Gagundali, Lex Administratum, November, Vol. V, Nomor 9,2017:175).

Berdasarkan hasil pemeriksaan ahli forensik ini, cedera atau memar seseorang akan diketahui, unhealthiness seseorang atau kematian seseorang. dokter forensik dapat membantu tentang proses peradilan dalam hal (Arsyadi, Jurnal Ilmu Hukum Hukum Opini, Edisi 2, Vol. 2,2014: 60):

a. Pemeriksaan di TKP. Hal ini biasanya diminta oleh pihak berwenang dalam hal seseorang sekarat. Pemeriksaan oleh dokter forensik akan sangat penting dalam menentukan jenis kematian dan pada saat yang 
sama mengetahui penyebab kematian seseorang. Dalam keadaan ini, dokter akan membuat Visum et Repertum.

b. Pemeriksaan korban luka. Pemeriksaan ini dilakukan dengan tujuan sebagai berikut:

$>$ Ada atau tidak adanya penganiayaan.

$>$ Menentukan ada atau tidak adanya kejahatan atau pelanggaran kesusilaan.

> Untuk mengetahui usia seseorang.

> Untuk menentukan kepastian bayi yang meninggal dalam kandungan ibu.

Visum et Repertumdapat dikatakan sebagai bukti yang digunakan untuk menjelaskan suatu peristiwa dan sebagai pengganti bukti pada saat kejahatan. Oleh karena itu, dapat dikatakan bahwa Visum et Repertum adalah bukti yang sah sebagaimana ditegaskan dalam Pasal 184 ayat (1) Undang-Undang Nomor 8 Tahun 1981 tentang KUHAP. Dengan demikian, dapat dikatakan nilai Visum et Repertum hanya sebagai penjelasan dan sebagai dasar untuk hakim dalam menambahkan keyakinan dalam mengambil keputusan kasus pidana. Sebagai bukti hukum atau sebagai pernyataan, post mortem dapat memperkuat keyakinan hakim, sehingga visum harus memenuhi persyaratan formal dan material pertama.

\section{B. Kekuatan Bukti Bukti Visum et Repertum}

Dalam yurisprudensi, ada doktrin yang menyatakan bahwa bukti dalam hukum acara pidana digunakan untuk mencari kebenaran materiil, sedangkan, dalam hukum acara perdata, tujuan bukti untuk menemukan kebenaran formal. kebenaran materiil menyatakan bahwa kebenaran tidak cukup untuk dibuktikan berdasarkan bukti formal, tetapi harus berdasarkan bukti lain berupa pernyataan lain yang terjadi di balik kasus. Oleh karena itu, hakim pidana tidak harus berhenti hanya dengan melihat dan memeriksa bukti yang diberikan tanpa berusaha untuk serius mengeksplorasi untuk menemukan kebenaran yang mungkin tersembunyi. Namun sebaliknya, hakim sipil hanya bergantung pada bukti diketahui dari bukti formal, seperti surat dalam bentuk akta otentik yang dibuat oleh pejabat publik atau surat dibuat tanpa perantara dari pejabat publik.

Kasus seperti ini berbeda dari doktrin kebenaran material, di mana kebenaran materiil harus ditemukan oleh hakim dalam proses pemeriksaan. Dalam hal ini, hakim tidak hanya harus melihat fakta-fakta yang muncul, tanpa memahami fakta-fakta yang terjadi di balik kasus ini. Dengan memahami dan meneliti secara mendalam bukti, hakim dapat memperoleh keyakinan tentang kebenaran fakta-fakta yang digunakan sebagai dasar pengambilan keputusan yang adil. Hukum pidana memiliki 
prinsip yang menjelaskan bahwa pada dasarnya, semua bukti yang diajukan dalam sidang memiliki kekuatan yang sama bukti. Hakim memiliki kebebasan untuk menilai sejauh mana bukti yang diajukan dalam persidangan (Anggun, Versitek, Vol 7, No 1, Januari-April 2019: 172).

Dalam hal ini, peran dokter dalam menemukan kebenaran yang adil dalam masalah hukum sangat penting. Bidang hukum dan kedokteran tidak dapat dipisahkan dalam penegakan hukum, khususnya dalam membuktikan kesalahan seseorang. Dalam keadaan ini, hanya dokter yang tahu bukti berupa bagian tubuh manusia. Oleh karena itu, mengingat pentingnya peran dokter ini dalam membuat bukti medis, perlindungan hukum diperlukan untuk dokter.

Upaya yang dilakukan untuk menemukan kebenaran materiil dalam kasus pidana untuk menghindari kesalahan dalam membuat keputusan. Hal ini ditekankan dalam Pasal 6 ayat (2) Undang-Undang Nomor 14 Tahun 1970 tentang Ketentuan Pokok Kekuasaan Kehakiman yang menyatakan "Tidak ada yang bisa dihukum karena kejahatan, kecuali jika pengadilan karena alat pembuktian yang sah menurut UU memiliki keyakinan bahwa seseorang yang dianggap bertanggung jawab, bersalah karena tindakan yang dituduhkan terhadap dirinya."

Berdasarkan Pasal 184 ayat (1) dari KUHAP, valid bukti terdiri dari:

a. Pernyataan saksi.

b. pernyataan ahli.

c. Surat.

d. Petunjuk.

e. Pernyataan terdakwa.

Dalam hal ini, bukti Visum et Repertum dikategorikan sebagai bukti. Hal seperti diatur dalam Pasal 187 dari KUHAP yang menyatakan "Surat itu dimaksud dalam Pasal 184 ayat (1) huruf c, dilakukan pada sumpah jabatan atau dikuatkan dengan sumpah adalah:

a. Menit dan surat-surat lainnya dalam bentuk resmi yang dibuat oleh pejabat publik yang berwenang atau dibuat sebelum dia, yang berisi informasi tentang peristiwa atau keadaan yang didengar, dilihat atau dialami oleh dirinya sendiri, disertai dengan alasan yang jelas dan tegas untuk laporan mereka.

b. Surat dibuat sesuai dengan ketentuan perundang-undangan atau surat yang dibuat oleh pejabat mengenai hal-hal yang termasuk dalam prosedur yang mereka bertanggung jawab dan yang dimaksudkan untuk bukti situasi. 
c. Sebuah pernyataan dari seorang ahli yang berisi pendapat berdasarkan keahliannya mengenai sesuatu atau situasi yang diminta secara resmi dari dia.

d. Surat lain yang hanya bisa berlaku jika itu ada hubungannya dengan isi dari alat bukti lain."

Dengan demikian, Visum et Repertum dikategorikan sebagai bukti dalam bentuk surat. Hal ini karena Visum et Repertum adalah pernyataan yang dibuat secara tertulis oleh seorang ahli di bidang kedokteran kehakiman dan dilakukan sumpah jabatan. Dengan melihat hal ini, dapat dikatakan bahwa post mortem dianggap sebagai bukti dokumenter dan tidak bukti ahli (Lasut, Lex nullum, Vol. V, No 3, Maret 2016: 123).

Berdasarkan ketentuan pasal 184 ayat (1) huruf c di atas, dapat disimpulkan bahwa bukti Visum et Repertum adalah surat yang dibuat oleh seorang pejabat dan dibuat pada sumpah berdasarkan ketentuan peraturan perundang-undangan. Oleh karena itu, post mortem termasuk dalam kategori bukti surat. Oleh karena itu, Visum et Repertum bukti memiliki nilai terbukti dalam persidangan.Namun, bukti Visum et Repertum bukan yang terkuat. Hal ini sesuai dengan sistem bukti pidana di Indonesia yang menganut sistem bukti berdasarkan hukum negatif, seperti ditegaskan dalam Pasal 183 dari KUHAP yang menegaskan "Hakim tidak harus memaksakan kriminal pada seseorang, kecuali jika dengan setidaknya dua potong bukti yang sah ia memperoleh keyakinan bahwa kejahatan telah benar-benar terjadi dan bahwa terdakwa bersalah karena melakukan hal itu."

Hakim harus mempertimbangkan semua fakta hukum dalam proses pembuktian di persidangan dengan menggunakan bukti-bukti yang terkandung dalam Pasal 184 ayat (1) dari KUHAP termasuk keterangan saksi, keterangan para ahli, surat, petunjuk, dan keterangan terdakwa (Permana, dkk, Jurnal Ilmu Hukum Universitas Jember, Vol. 1, No. 1, 2013:2). Ketentuan mengandung konsekuensi bahwa dalam hukum pidana di Indonesia tidak ada satu bukti yang bisa dikatakan sebagai bukti kuat, karena dalam setiap keputusan pidana membutuhkan setidaknya dua alat bukti yang sah ditambah dengan keyakinan hakim (Nisa Dan Krisnan, Varia Justicia, Vol. 11, No. 1, 2015: 196-197). Oleh karena itu, Visum et Repertum bukti sebagai bukti surat yang diajukan tidak bisa mandiri dan harus dilengkapi dengan bukti lain oleh ketentuan Pasal 184 dari KUHAP.

Informasi yang diperoleh dari Visum et Repertum bukti dapat menentukan ada atau tidak adanya tindak pidana dalam membantu untuk menyelidiki kejahatan terhadap tubuh manusia dan kehidupan yang merupakan tugas utama dari seorang dokter. Dengan demikian, dapat dikatakan bahwa Visum et Repertum bukti sebagai pengganti peristiwa 
yang terjadi dan harus dapat sepenuhnya menggantikan bukti yang telah diperiksa oleh mengandung semua fakta, sehingga nantinya bukti yang telah diperiksa dapat menghasilkan kesimpulan adil (Yohana, Skripsi, Purwokerto: Universitas Jenderal Soedirman, 2015: 91).

Visum et Repertummemiliki kegunaan lain dalam menentukan tuduhan bahwa akan dibawa ke hakim terhadap terdakwa. dokter forensik harus memeriksa dan mengumpulkan berbagai bukti yang terkait dengan pemenuhan unsur-unsur tindak pidana sebagaimana diatur dalam UndangUndang dan mengkompilasi laporan Visum et Repertum. Dengan adanya Visum et Repertum, peneliti dapat memperoleh informasi yang berguna untuk memenuhi unsur pidana, apakah tindak pidana yang ringan atau tidak penganiayaan. Dengan demikian, penyidik dapat menentukan tuduhan yang mungkin kemudian diserahkan kepada hakim terhadap terdakwa berdasarkan pemenuhan unsur-unsur tindak pidana yang berlaku berdasarkan Undang-Undang.

\section{Penyalahgunaan Bukti Visum et Repertum dan Pemerasan Kejahatan}

Visum et Repertum bukti-bukti yang sah sebagaimana diatur dalam Pasal 162 dan Pasal 179 ayat (2) dan ditegaskan dalam Pasal 187 huruf c KUHAP. Namun, hal itu dapat menjadi celah dan kelemahan bahwa bukti ini dapat disalahgunakan dan dilakukan untuk melakukan tindak pidana, salah satunya adalah kejahatan pemerasan. Kejahatan pemerasan adalah tindakan yang melanggar hukum yang dilakukan dengan sengaja atau tidak sengaja oleh seseorang yang tindakannya dapat dipertanggungjawabkan dan oleh UU dinyatakan sebagai tindakan yang melanggar hukum dan dapat dihukum.

Di Belanda, pemerasan berasal dari kata afpersing, yang berarti kejahatan pemerasan atau pemerasan. Pasal 368 ayat (1) KUHP menyatakan bahwa "siapa saja yang memiliki niat untuk menguntungkan diri sendiri atau orang lain secara melawan hukum, pasukan seseorang dengan kekerasan atau ancaman kekerasan untuk memberikan sesuatu, yang seluruhnya atau sebagian dimiliki oleh orang tersebut atau seseorang lain, atau supaya utang membuat atau menulis off piutang, terancam karena pemerasan dengan pidana penjara tidak lebih dari sembilan tahun."

Adapun unsur-unsur yang terkandung dalam Undang-Undang Pidana pemerasan dengan penghinaan, termasuk:

1. unsur obyektif, yang terdiri dari:

a. tindakan paksa.

b. Yang terpaksa (orang)?

c. Cara untuk kekuatan dengan menggunakan:

Ancaman pencemaran nama baik, baik tertulis maupun lisan.

https://journal.unnes.ac.id/sju/index.php/lsIr/

UKM Lex Scientia, Fakultas Hukum Universitas Negeri Semarang 
Ancaman akan membuka rahasia.

d. Unsur Tujuan yang sekaligus akibat dari:

$>$ Orang-orang yang memberikan sebuah benda yang sebagian atau seluruhnya dimiliki oleh orang lain.

$>$ Orang yang memberi utang.

$>$ Orang yang membatalkan piutang.

2. unsur subjektif, termasuk:

a. Dengan maksud:

$>$ Keuntungan diri Anda sendiri.

$>$ Manfaat lain.

b. Dengan melanggar hukum.

Kejahatan pemerasan sebagaimana diatur dalam KUHP terdiri dari dua jenis tindak pidana, yaitu tindak pidana pemerasan dengan kekerasan dan ancaman kekerasan dan kejahatan pemerasan dengan penghinaan. Hari ini, metode yang digunakan oleh para pelaku pemerasan tidak lagi ancaman, tetapi dengan cara menghina atau mengungkapkan rahasia. rahasia mengungkapkan cara memberitahu orang ketiga atau masyarakat umum tentang hal-hal tentang orang terancam atau orang ketiga dalam hubungan dengan orang yang sedang terancam.

Dalam situasi ini, rahasia yang bersangkutan tidak hanya tentang sesuatu yang harus disimpan oleh pelaku ancaman, tapi bisa tentang apa saja yang terancam oleh orang yang diinginkan dan tidak ingin dikenal oleh banyak orang. Dengan demikian, rahasia ini memiliki arti yang berbeda dari rahasia sebagaimana dimaksud dalam Pasal 322 KUHP tentang pengungkapan rahasia oleh orang yang karena jabatannya atau pekerjaan wajib menjaga rahasia (Hardiman, Skripsi, Makassar, Universitas Hasanuddin, 2017: 26-27).

Dalam kasus di mana seseorang dengan sengaja melakukan atau memprovokasi cedera atau hal yang berhubungan dengan tubuh manusia dan kemudian orang tersebut membuat pertahanan menyebabkan cedera pada tubuh seseorang, maka menurut ketentuan Pasal 49 ayat (1) dari Hukum Pidana negara hukum "Tidak dihukum, siapa saja yang melakukan perbuatan pertahanan dipaksa untuk dirinya sendiri atau untuk orang lain, kesusilaan atau properti sendiri atau orang lain, karena ada serangan atau ancaman serangan dekat pada saat itu yang melawan hukum". Dalam hukum pidana, pertahanan seperti ini dikenal sebagai noodweer. Oleh karena itu, berdasarkan Pasal 49 ayat (1), orang yang melakukan seperti pembelaan diri tidak dapat dihukum (divonis). Namun, hal ini lagi berdasarkan bukti yang cukup. Pada kasus ini, korban pemerasan yang diduga melakukan penganiayaan harus dapat membuktikan bahwa korban penganiayaan adalah pelaku pemerasan ini yang sengaja manfaat dirinya. 
bukti ini adalah dengan ketentuan sebagaimana Pasal 184 dari KUHAP yang mengatur bukti hukum, dengan setidaknya dua potong bukti yang sah terpenuhi.

Penggunaan Visum et Repertum bukti melawan hukum tidak jelas menjelaskan, tetapi penggunaan Visum menjadi haram jika post mortem terjadi menjadi alat perbuatan melawan hukum sebagaimana dirumuskan dalam norma setiap kejahatan. Dapat dikatakan bahwa kekuatan bukti Visum et Repertum hanya sebagai instrumen pelengkap dalam mencari kebenaran. Seseorang yang dengan sengaja menggunakan post mortem untuk keuntungan secara ilegal, dalam hal ini, telah menjadi korban dari tindakan penganiayaan. Namun, dalam kondisi seperti itu, ia juga memiliki niat dan niat hati yang lain terhadap sesuatu yang menimpa dirinya dengan memanfaatkan situasi menggunakan Visum et Repertum bukti melawan hukum. Berdasarkan analisis unsur pidana dalam aliran monistik dan unsur pertanggungjawaban pidana dalam aliran dualistik, pelaku kejahatan ini telah memenuhi unsur Dolus. Ini berarti bahwa seseorang telah memiliki tindakan yang disengaja dan disengaja untuk mendapatkan kecil atau luka parah dengan maksud untuk menguntungkan diri sendiri secara ilegal.

\section{KESIMPULAN}

Visum et Repertumdapat dikatakan sebagai bukti yang digunakan untuk menjelaskan suatu peristiwa dan sebagai pengganti bukti pada saat kejahatan. Oleh karena itu, dapat dikatakan bahwa Visum et Repertum adalah bukti yang sah sebagaimana ditegaskan dalam Pasal 184 ayat (1) Undang-Undang Nomor 8 Tahun 1981 tentang KUHAP. Dengan demikian, dapat dikatakan bahwa nilai Visum et Repertum hanya kejelasan dan sebagai dasar bagi hakim untuk meningkatkan kepercayaan diri mereka dalam membuat keputusan kasus pidana. Visum sebagai bukti hukum atau informasi yang dapat memperkuat keyakinan hakim, maka visum et Repertum harus memenuhi persyaratan formal dan material pertama.

Berdasarkan ketentuan pasal 184 ayat (1) huruf c, dapat disimpulkan bahwa bukti Visum et Repertum adalah surat yang dibuat oleh seorang pejabat dan dibuat pada sumpah berdasarkan ketentuan peraturan perundangundangan. Oleh karena itu, post mortem termasuk dalam kategori bukti surat. Oleh karena itu, Visum et Repertum bukti memiliki nilai terbukti dalam persidangan. Proses pembuktian di persidangan sangat diperlukan. Hal ini sebagaimana ditegaskan dalam Pasal 179 ayat (1) Undang-Undang Nomor 8 Tahun 1981 tentang KUHAP, yaitu "Setiap orang diminta pendapatnya sebagai ahli medis peradilan atau dokter atau ahli lain harus memberikan 
informasi ahli hukum." Namun, Seseorang yang dengan sengaja menggunakan post mortem untuk keuntungan secara ilegal, maka orang tersebut tidak dapat dianggap sebagai korban tapi pelaku lain yang berhubungan dengan saksi. Berdasarkan analisis unsur pidana dalam aliran monistik dan unsur pertanggungjawaban pidana dalam aliran dualistik, para pelaku kejahatan ini telah memenuhi unsur Dolus. Ini berarti bahwa seseorang telah memiliki tindakan yang disengaja dan disengaja untuk mendapatkan kecil atau luka parah dengan maksud untuk menguntungkan diri sendiri secara ilegal.

\section{E. DAFTAR PUSTAKA}

Pasal 28 G UUD 194 Republik Indonesia

Pasal 1 ayat (1) dari Kode Hukum Pidana

Moh. Saleh Djindang, Pengantar dalam Hukum Indonesia, Jakarta: Ichtiar Baru dan Sinar Harapan 1983, p. 338

Dilla Haryanti, Peranan Visum et Repertum sebagai Salah Ssatu Alat Bukti di Persidangan dalam Tindak Pidana Perkosaan, Jurnal Constitutum, Vol.13, No. 1, 2013, p.602

Setyo Trisnadi, Ruang Lingkup Visum et Repertum sebagai Alat Bukti pada Peristiwa Pidana yang Mengenai Tubuh Manusia di Rumah Sakit Bhayangkara Semarang, Sains Medika, Vol.5, No.2, Juli-Desember 2013, p.126

Siswo Putranto Santoso, Analisis Peran Visum et Reperum pada Pelaku Penganiayaan, Ditinjau dari Pasal 351 ayat (1) Kitab Undang-Uundang Hukum Pidana (KUHP) (Studi Kasus Perkara Nomor:257 /Pid.B / 2014 / PM. Cibadak, Jurnal Ilmiah Widya, Vol.3, No.3, Jjanuari-Juli 2016, p/129

Antory Royan Adyan, Kekuatan Hukum Visum et Repertum sebagai Alat

Bukti Ditinjau dari KUHAP dan Undang-Undang Nomor 23 Tahun 2004, Keadilan Progresif, Vol.1, No.1, 2010, p.36

Hamidah Siadari, Nur Rochaeti, dan Bambang Dwi Baskoro, Arti Penting

Visum et Repertum sebagai Alat Bukti Perkosaan, Diponegoro Law Journal, Vol.5, No.3, 2016, hlm.10-11

Deysky Neidi Gagundali, Visum et Repertum sebagai Alat Bukti dalam

Perkara Tindak Pidana Penganiayaan Ringan * Menurut Kitab UndangUndng Hukum Acara Pidana, Lex Adminitratum, November 2017, Vol.V, Nomor 9, p.175

Arsyadi, Fungsi dan Kedudukan Visum et repertum dalam Perkaa Pidana, Jurnal Ilmu Hukum Opini, 2014, Edisi 2, Vol.2, p.60 
Narulita Anggun, Kekuatan Pembuktian dan Penilaian Alat Bukti Visum et Repertum dalam Tindak Pidana Pembunuhan Berencana (Studi Putusan Pengadilan Negeri Staatsblad Nomor 416 / Pid.B / 201 / PN.Stb, Versitek, Vol 7, No 1, Januari-April 2019, p.172

Mario Lasut, Visum et Repertum sebagai Alat Bukti dalam Tindak

Agustin L. Hutabarat, Kekuatan Visum et Repertum sebagai Alat Bukti, 2013,

Tersedia di https://www.hukumonline.com/klinik/detail/ulasan/lt51b4b7977c299 /kekuatan-visum-et-repertum-sebagai-alat-bukti , diakses 19 Mei 2019

Agung Permana, Samsudi, dan Ainul Azizah, Analisis Yuridis Pembuktian oleh Hakim terhadap Tindak Pidana Penganiayaan dikaitkan mencari Google Artikel Pembuktian * Menurut KUHAP (Putusan Nomor : 110 / Pid. B /2010 / PN / JR) Jurnal Ilmu Hukum Universitas Jember, Vol.1, No.1, 2013, p. 2

Fajar Hardiman, Skripsi: "Tinjauan Yuridis erhadap Tindak Pidana Pemerasan Mencari Google artikel Ancaman Kekerasan (Studi Kasus Pputusan Nomor 43/Pid.B/2015/PN.Mrs"(Makassar:Universitas Hasanuddin, 2017), hlm.26-27 
ADAGIUM HUKU

\section{Culpue Poena Par Esto}

Jatuhkanlah Hukuman yang Setimpal Dengan Perbuatan 